\title{
Biosphere 2 experiments with scientific visits
}

Washington. As a new team of inhabitants re-occupied the huge, hermetically sealed Arizona greenhouse known as Biosphere 2 this week, there are signs that the rift between the US scientific establishment and the private sponsors of the $\$ 150$ million facility may be healing.

Six so-called Biospherians entered the three-hectare attempt to replicate the global ecosystem on Sunday, and will spend between four months and a year under glass. But in contrast to the initial two-year occupation of the facility which ended last September, the second stint of experimentation will include the arrival and departure of outside scientists for shorter periods in order to work and collect data.

The change in strategy has boosted hopes among the supporters of Biosphere 2 that some of the rigorous science that its detractors have accused it of neglecting will now be done.

Publication of work from the first phase of inhabitation - including scientific papers on oxygen loss by Wallace Broecker of the Lamont-Doherty Earth Observatory and others (see EOS 75, 33; 1994), and on health effects by Roy Walford of the University of California at Los Angeles (see Proceedings of the National Academy of Sciences 89, 11533 ; 1992) - has bolstered the credibility of the facility.

"I guess that gives us some sort of stamp of approval," says Jack Corliss, a former oceanographer who moved from doing computer modelling work on evolution at NASA to become Biosphere 2's research director last March. As Corliss arrived, the facility's outside advisory panel disbanded itself, citing various differences with Space Biospheres Ventures (SBV), the private company which owns and operates the experiment.

Biosphere 2's many critics, including members of the defunct advisory panel, say they hope that the more flexible structure of the new phase of operation will increase the usefulness of the facility. But they remain scathing about the organization of the project.

"I still don't think they are doing any science," says former panel member Gerald Soffen, director of university programmes at NASA's Goddard Space Flight Center in Maryland. "The design and construction are great, but it hasn't proven itself." But Soffen says he hopes that outside scientists will now get involved in exploiting the "terrific capability" of the facility.

Paid for mainly by Texan billionaire Edward Bass, Biosphere 2 attempted to house eight people in almost complete isolation. It was widely ridiculed when one inhabitant had to leave for medical treatment, and when special equipment, such as carbon dioxide scrubbers, had to be added to sustain the experiment. More seriously, critics charged that before the arrival of Corliss the programme lacked a research director or a serious scientific agenda.

But the project, whose name alludes to the Earth as Biosphere 1, has also become a symbol for those in the environmental sci-

IMAGE
UNAVAILABLE FOR
COPYRIGHT
REASONS

iosphere 2 hopes to answer the critics.

ence community who claim there are shortcomings in traditional scientific methods

"The average scientist is a reductionist," says Eugene Odum of the Institute of Ecology at the University of Georgia, who also served on the advisory panel. Odum says

\section{Warning on cancer gene screening}

San Francisco. The National Institutes of Health's (NIH's) National Advisory Council for Human Genome Research is due to issue a warning this week that genetic screening tests for susceptibility to cancer should not become widely used before adequate research has been carried out on their utility, as well as their likely impact on patients.

The warning comes in a statement published in a leading medical journal, urging physicians to avoid using such tests - apart from small controlled research studies until issues of quality assurance, counselling, medical implications and the dangers of genetic discrimination can be resolved.

The statement is likely to call for coordinated research on such questions, and NIH has already issued a request for proposals for research in such fields.

The council's statement is being made partly in response to an announcement in December by Oncor Inc., a Maryland biotechnology company, that it plans to begin offering linkage analysis for markers associated with a gene implicated in about 10 per cent of breast cancers, as well as in some ovarian cancers.

Oncor has come under criticism from geneticists who argue that no test will be able to provide reliable information about susceptibility to breast cancer until the gene involved has been cloned.

But Doug Dolginow, president of Oncor that, by looking at a complete ecosystem, Biosphere 2 "has a top-down approach which is the ecological approach. It is as much a human experiment as a scientific one."

The original Biospherians, all of whom were nonscientists, were "resourceful individuals with survival skills," says Odum. "Scientists wouldn't have worked in there; they would be so cantankerous they'd end up killing each other."

Corliss says he is "fairly confident" that the new team has moved along the path of making the project ecologically independent, and that the experiment can now move on to a more flexible regime that will open it up to more visiting scientists.

There will be no new advisory panel. According to Corliss. "We don't need an advisory panel, we have advisory scientists." Such panels are all right for government-funded work, he says, but his project represents "a more entrepreneurial way of organizing things and doing research." $\mathrm{He}$ suggests that NASA would have required ten times as much money to run the Biosphere 2 project, "and it still wouldn't be built yet."

Colin Macilwain

subsidiary OncorMed Inc., defends the company's plans by saying that it intends to carry out the analysis for only a small number of families with a confirmed hereditary pattern of cancer.

Each family will have been through counselling to ensure that they understand the significance of the test, he says, adding that the company also has a genetic screening test for colon cancer which it is only offering to patients in research studies until more is known about the effects of the gene.

According to Dolginow, Oncor agrees with the main thrust of the genome council's warning about cancer screening tests, and accepts that a significant amount of further research is necessary before genetic tests become commercially feasible. But it also believes that enough data already exist about the genetic linkage of breast cancer to make its analysis reliable.

David Galas, who was responsible for the US portion of the $\$ 3$ billion Human Genome Project until late last year, and is currently vice-president of research at Darwin Molecular Corp. in Washington state, says that such tests need to be introduced carefully, as they challenge assumptions about civil rights, privacy and individual responsibility. In California, a bill that would prohibit genetic discrimination by health insurers has passed the state senate and is awaiting a committee hearing in the state assembly.

Sally Lehrmann 